International Research Journal of Management, IT \& Social Sciences
Available online at https://sloap.org/journals/index.php/irjmis/
Vol. 6 No. 3, May 2019, pages: $1 \sim 10$
ISSN: 2395-7492
https://doi.org/10.21744/irjmis.v6n3.621

\title{
The Fraud Diamond: Element in Detecting Financial Statement of Fraud
}

\author{
RR. Maria Yulia Dwi Rengganis ${ }^{\text {a }}$ \\ Maria Mediatrix Ratna Sari ${ }^{b}$ \\ I.G.A.N Budiasih ${ }^{\mathrm{c}}$ \\ I Gde Ary Wirajaya ${ }^{\mathrm{d}}$ \\ Herkulanus Bambang Suprasto ${ }^{\mathrm{e}}$
}

\section{Article history:}

Received: 27 December 2018

Accepted: 31 March 2019

Published: 9 April 2019

\section{Keywords:}

capability;

fraud diamond;

opportunity;

pressure;

rationalization;

\begin{abstract}
The financial statement fraud is generally difficult to be detected, because of the various motivations behind the actions taken. The purpose of this research is to analyze the elements of fraud diamond in detecting financial statement fraud by looking at the influence of variables into a proxy of the elements of fraud diamond on financial statement fraud. The population of this research is the entire financial sector companies registered in BEI 2013-2017 period. Purposive sampling technique was used to determine sample research. The company elected to sample as many as 46 companies. The research method used is the method of multiple linear regression analysis. The results of the analysis of this study are pressure elements showing only financial target variables have positive effect on financial statement fraud. The opportunity element shows variable number for audit committees, independent commissioners and the number of audit committee meetings have negative affect. The rationalization element shows that the audit opinion variable has no effect on financial statement fraud. The capability element shows that the change of director's variable has no effect on financial statement fraud.
\end{abstract}

2395-7492@ Copyright 2019. The Author. This is an open-access article under the CC BY-SA license (https://creativecommons.org/licenses/by-sa/4.0/) All rights reserved.

\section{Author correspondence:}

RR. Maria Yulia Dwi Rengganis,

Universitas Udayana.

Denpasar, Bali, Indonesia

Email address: dwiyuliaa67@gmail.com

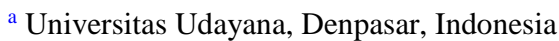

${ }^{\mathrm{b}}$ Universitas Udayana, Denpasar, Indonesia

c Universitas Udayana, Denpasar, Indonesia

${ }^{\mathrm{d}}$ Universitas Udayana, Denpasar, Indonesia

${ }^{\mathrm{e}}$ Universitas Udayana, Denpasar, Indonesia
} 


\section{Introduction}

The Act of manipulation of financial statements is one form of the Act of cheating or fraud. Australian Auditing Standard (AUS) defined financial statement fraud is a deliberate omission including serving amounts or disclosures in the financial statements to defraud users of financial reports (Brennan \& McGrath, 2007). Financial statement fraud often occurs in companies or government organizations. The company's losses due to fraud at the end can disrupt the stability of the company long-term, can even cause bankruptcy. One case of fraud that occurred in the financial sector in Indonesia is a case in PT Sunprima Nusantara financing (SNP finance). There are allegations that SNP finance has been detrimental to the 14 banks in Indonesia to about Rp14 trillion. Based on the results of the investigation, the company allegedly used forged documents, embezzlement, fraud (www.cnnindonesia.com). Other cases, i.e., cases of criminal acts of banking conducted by President Director (CEO) BPR KS BAS. The mode of "NS" conducted as a Director and Shareholder of PT BPR KS BAS is by instructing employees of BPR to process of granting credit to the debtor with 54 total value of Rp 24.225 billion in the period March-December 2014, but not appropriate procedures. The case of the SNP Finance and PT BPR KS BASS is just a small part of the overall case that occurs because there are still many cases of fraud relating to the financial statements (www.ekonomi.kompas.com).

Financial statement fraud detection is generally hard to do for a variety of motivations which aspects influenced these actions. The American Institute of Certified Public Accountant (AICPA) issued the Statement on Auditing Standards No. 99 (SAS No. 99) to provide solutions to the weaknesses in the procedures for detecting fraud in the world (Skousen et al., 2009). Meanwhile, the International Federation of Accountants (IFAC), publishes the International Standards on Auditing (ISA) (Wahyuni Budiwitjaksono, 2017). In these standards, there is an illustration of the factors of cheating, that ISA No. 240 and SAS No. 99 based on the triangular theory of cheating or fraud triangle. This triangular theory propounded by Cressey (1953) which categorizes the three conditions of cheating in the company, i.e. the pressure, opportunity, and rationalization. Wolfe \& Hermanson (2004), developed the fraud triangle by adding a fourth element of "capability". Cheating is considered not going to happen without anyone capable. An element of pressure, opportunity, and rationalization capability referred to as fraud diamond.

Previous research on the detection of fraud in financial statements has been carried out by Manurung \& Rick (2015). The research results show that only the variable capability that influences positively against the financial statement fraud while others have no effect. Other similar research conducted by Poppy Indriani and m. Titan Terzaghi (2017), that shows the results of that Financial stability, Nature of industry influence on the financial statement fraud, while other variables in the research did not influential. The number of cases that occur is related to acts of financial statement fraud shows that the negative effects arising from the existence of acts of fraud on the company's financial reports and adverse parties. The financial statement fraud is very important to be detected, so that related parties can perform acts of anticipation to prevent large losses.

This research aims to conduct an analysis of the elements of fraud diamond in detecting financial statement fraud. Elements of fraud diamond cannot be casually researched so need a proxy of each element. How to detect cheating by using financial reports fraud diamond model is to look at the influence of variables into a proxy of the elements of fraud diamond on financial statement fraud. Fraud diamond consists of elements of pressure, opportunity, rationalization, and capabilities. Pressure element is proxied with the variable of external pressure, financial stability, and financial targets. Chance element is proxied with the variable of a number of the audit committee, the independent Commissioner, and the number of audit committee meetings. The rationalization element in this study is proxied by the audit opinion variable. The capability element in this study is proxied by the change of director's variable.

\section{Literature Review and Hypothesis}

Fraud diamond Theory. At first, appeared an idea invented by Donald r. Cressey (1953), about the professional literature on SAS No. 99 and ISA No. 240, called the fraud triangle or triangular cheating. Fraud triangle describes the pressure factor, opportunity, and rationalization. Wolfe \& Hermanson (2004), later developed by Cressey (1953), became the fraud diamond theory by adding one element IE element capability. According to David T. Wolfe \& Dana Hermanson (2004), fraud will not occur without the existence of the right people with the right capabilities. Open the door of opportunity fraud, pressure and rationalization can attract people to commit fraud. But all this will not happen without the presence of someone who has the ability to recognize opportunities as an opportunity and take advantage of these (Rahmayuni, 2017).

The stability of the financial condition of the company can be seen of the owned assets because assets show the wealth owned by the company (Rahmawati et al., 2017). Fraud can arise when management companies get pressure 
to show that the company has been able to manage their assets well. Percentage change in total assets indicating the presence of fraud in financial statements, due to the high percentage change total assets as a way to show earning power of the company and a stronger financial position (Indriani \& Terzaghi, 2017). Research conducted by Skousen et al., (2009) proved that the greater the ratio of the change in total assets of a company then the probability of doing acts of cheating on financial statements the company is getting higher. Based on the description, the research hypothesis is proposed as follows:

$\mathrm{H}_{1}$ : Financial stability has a positive effect on financial statement fraud

One of the pressures often experienced by company's management is the need to obtain additional debt or external financing sources to remain competitive, including financing research and development or capital expenditures resulting from financing through debt (Skousen et al., 2009). External financing needs related to cash generated from debt in this study are proxied by leverage ratio (Sihombing, 2014). Research conducted by Skousen et al., (2009), shows that the percentage of total debt to total assets (LEV) has a positive effect on financial statement frauds. Similar results are also proven through Dalnial et al., (2014), a study which found that total debt for total assets is a significant aspect that influences fraud. Based on the description, the research hypothesis is proposed as follows:

$\mathrm{H}_{2}$ : External pressure has a positive effect on financial statement fraud

Based on SAS No. 99, financial targets are excessive pressure on management to achieve financial targets set by directors or management. The existence of a financial target causes the company to manipulate earnings to meet analyst estimates or benchmarks such as the previous year's profit (Prasastie, 2015). Return on Assets (ROA) is a broad measure of operating performance used to show how efficiently assets have been used (Skousen et al., 2009). The results of research conducted by Indarti et al., (2016), show that financial targets have an effect on fraudulent financial reporting. The higher the ROA targeted by the company, the more vulnerable the management will be to manipulate earnings which is one form of fraud so that it has a positive relationship with financial statement frauds. Based on the description, the research hypothesis is proposed as follows:

$\mathrm{H}_{3}$ : Financial targets have a positive effect on financial statement fraud

The element of chance shows the existence of opportunities that allow fraud to occur are usually caused due to lack of supervision, internal oversight of an organization is weak/ineffective, and abuse of authority (Ristianingsih, 2017). Beasley et al., (2000) in Skousen et al., (2009), observed that the company that owns the audit committee can reduce cheating that is going on in the company. Earlier research conducted by Lin et al., (2006), also shows that the greater number of members of the audit committee in a company, then errors in the financial statements will be getting smaller. Based on the description, the research hypothesis is proposed as follows:

$\mathrm{H}_{4}$ : The number of audit committees negatively affects cheating financial statement

The element of chance shows that there is a chance of occurrence of fraud caused by ineffective monitoring. SAS No. 99 explained that ineffective monitoring can occur due to the dominance of management by a single person or a small group, and no effective supervision over the financial reporting process, internal control and the like. The independent Commissioner is a member of the Board of Commissioners who are eligible not affiliated either with the controlling shareholder, Director or Commissioner, does not duplicate work with affiliated companies (Effendi, 2008). The results of research conducted by Tiffani \& Marfuah (2015), shows that ineffective monitoring effect on financial statement fraud. The Board of Commissioners as independent parties who got no pressure by the internal organization of the company are likely to be acting independently and act as a separator between the interests of the principal and the agent. Therefore, the existence of independent Commissioners in the company expected to increase surveillance against management in managing the company and can reduce the likelihood of the occurrence of the financial statement fraud. Based on the description, the research hypothesis is proposed as follows:

$\mathrm{H}_{5}$ : Independent Commissioner has a negative influence on financial statement frauds

The number of meetings of the audit committee is basically produce the quality of the monitoring conducted by the audit committee. In carrying out its duties, the audit committee members must perform coordination of fellow members and discussing the findings of monitoring and analysis that is conducted is related to the company's Financial Reports (Mutmainnah \& Wardhani, 2013). The research of Abbot et al., (2004) proves that companies with audit committees that meet at least four times a year tend not to restatement financial statements so that there will be a negative relationship between the number of audit committee annual meetings and financial statement frauds. Thus, the high

Rengganis, R. M. Y. D., Sari, M. M. R., Budiasih, I., Wirajaya, I. G. A., \& Suprasto, H. B. (2019). The fraud diamond: element in detecting financial statement of fraud. International Research Journal of Management, IT and Social Sciences, 6(3), 1-10. https://doi.org/10.21744/irjmis.v6n3.621 
intensity of the implementation of audit committee meetings represents a better monitoring process that is carried out and can further reduce the chances of financial statement frauds. Based on the description, the research hypothesis is proposed as follows:

$\mathrm{H}_{6}$ : The number of audit committee meetings has a negative effect on financial statement frauds

The audit opinion is the auditor's statement on the fairness of the financial statements of the audited entity. Based on SA 700 there are 2 types of opinions expressed by the auditor, namely opinions without modification and opinions with modifications. The auditor must state the opinion without modification if the auditor concludes that the financial statements are prepared in all material respects in accordance with the applicable financial reporting. The audit opinion included in the Opinion without modification is an unqualified audit opinion. Skousen et al., (2009), proves that audit opinions negatively affect financial statement frauds. In accordance with this explanation, if a company obtains an unqualified opinion, it can be believed that the company's financial statements have been prepared in accordance with the applicable provisions and free from material misstatement. The research hypothesis is proposed as follows:

$\mathrm{H}_{7}$ : The audit opinion has a negative effect on financial statement fraud

Wolfe \& Hermanson (2004), explain what is meant by the element of capability is the position of someone in the organization can provide the ability to take advantage of opportunities to commit fraud. The regulation in Article 105 paragraph (1) of the Company Law, said that members of the Board of Directors and the board of commissioners may be terminated at any time based on the decision of the General Meeting of Shareholders (GMS) stating the reasons. Changes to directors are generally loaded with political content and the interests of certain parties that trigger the emergence of conflicts of interest (Purba \& Putra, 2017). Wolfe \& Hermanson (2004), examined capability as one of the fraud risk factors underlying the occurrence of fraud, concluding that changes in directors could indicate fraud. Based on the description, the research hypothesis is proposed as follows:

$\mathrm{H}_{8}$ : Changes of the Board of Directors has a positive effect on the financial statement fraud

\section{Materials and Methods}

The population in this research is the entire financial sector companies registered in BEI 2013-2017 period. Financial sector companies as research objects because based on the Study Report to The Nations 2016 belongs to ACFE stated that the type of the organization or company that is most heavily involved in the fraud case is banking and service companies Finance. The technique of collecting samples in this research is purpose sampling. Method of data collection in this study using the method of documentation and study of the literature. Types of Data used in this research is quantitative data. The source of the data used in this study belongs to the secondary data. Research methods used in this research is a method of multiple linear regression analysis. Multiple linear regression analysis method aimed to know the influence of the independent variables on the dependent variable.

\section{Results and Discussions}

Multiple linear regression analysis method aimed to know the influence of the independent variables on the dependent variable:

Tabel 1

Multiple Linear Regression Analysis Results

\begin{tabular}{|c|c|c|c|c|c|}
\hline \multirow[b]{2}{*}{ Variabel } & \multicolumn{2}{|c|}{$\begin{array}{l}\text { Unstandardized } \\
\text { Coefficients }\end{array}$} & \multirow{2}{*}{$\begin{array}{c}\text { Standardized } \\
\text { Coefficients } \\
\text { Beta }\end{array}$} & \multirow[b]{2}{*}{$\mathrm{t}$} & \multirow[b]{2}{*}{ Sig. } \\
\hline & $\mathrm{B}$ & Std, Error & & & \\
\hline (Constant) & 1,436 & 0,259 & & 5,545 & 0,000 \\
\hline ACHANGE & 0,034 & 0,046 & 0,024 & 0,737 & 0,462 \\
\hline LEV & $-1,468$ & 0,110 & $-0,581$ & $-13,308$ & 0,000 \\
\hline ROA & 2,663 & 0,697 & 0,162 & 3,821 & 0,000 \\
\hline ACSIZE & $-0,099$ & 0,018 & $-0,203$ & $-5,545$ & 0,000 \\
\hline
\end{tabular}




\begin{tabular}{lrrrrr} 
BDOUT & $-0,486$ & 0,122 & $-0,146$ & $-3,993$ & 0,000 \\
ACMEET & $-0,261$ & 0,103 & $-0,088$ & $-2,541$ & 0,012 \\
AUDREPORT & 0,170 & 0,230 & 0,024 & 0,738 & 0,461 \\
DCHANGE & $-0,041$ & 0,031 & $-0,044$ & $-1,336$ & 0,183 \\
$\mathrm{R}^{2}$ & & & & & 0,776 \\
F count & & & & & 95,919 \\
Significance F & & & & & 0,000 \\
\hline
\end{tabular}

Source: Processed data, 2018

Based on the results of the analysis on the table of the results of multiple linear regression analysis, the regression equation is then used in this research can be written as follows.

$$
\begin{aligned}
F-S C O R E= & 1,436+0,034 \text { ACHANGE }-1,468 \mathrm{LEV}+2,663 \mathrm{ROA}-0,099 \mathrm{ACSIZE}-0,486 \mathrm{BDOUT}-0,261 \mathrm{ACMEET} \\
& +0,170 \text { AUDREPORT }-0,041 \mathrm{DCHANGE}
\end{aligned}
$$

\subsection{The influence of financial stability at the financial statement fraud}

The results of the analysis show that financial stability has no effect on the financial statement fraud so that the first hypothesis (H1) is rejected. Financial stability in the study viewed from the change of the company's total assets. This means that the change in total assets of the company can not detect any financial statement. It can be caused due to changes in the value of the total assets of most companies tend to be insignificant or the company in a stable condition. Generally, the management companies that have been in stable financial condition, has no pressure to commit fraud. In addition, any change in the company's assets may occur not because of the financial statement fraud but rather the result of a strategy that is carried out by management in managing the assets of the company.

The results of this research are consistent with research conducted by Maghfiroh et al., (2015), as well as research from Norbarani (2012), also found that financial stability that proxied with CHANGE does not have a significant influence against the financial statement fraud. Financial stability is one of the proxies from the elements constituting the pressure element in the fraud of the diamond theory which is regarded as a motivation for doing the financial statement fraud. The results of this study indicate that financial stability can not be a motivation for committing fraud. Therefore, the results of this research can not support the fraud diamond theory.

\subsection{The influence of external pressures on the financial statement fraud}

The results of the analysis showed that the external pressures have a negative effect on the financial statement fraud so that the second hypothesis (H2) was rejected. This occurs because of the tendency of companies that perform financial statement fraud with low leverage ratio because the current creditors no longer consider the magnitude of the resulting leverage but rather because there are other considerations such as the existence of good relations between the company with the borrower. Other factors which are not supporting the second hypothesis (H2) because most companies did not finance assets by using debt. Changes that occur at the level of debt will have no effect on the decision of the company's management against the number of earnings that will be reported. This is because of the company's ability to pay off his loan interest along with the principal.

The results of this study support the research of Martantya \& Daljono (2013), as well as Ardiyani \& Utaminingsih (2015), stating that leverage has no effect against financial statement frauds. The external pressure is one element of the pressure that the proxy is an element of fraud in the diamond theory. Results of the study could not prove that the external pressure effect on the financial statement fraud. So, the results of this research can not support the fraud diamond theory.

\subsection{The influence of financial targets on the financial statement fraud}

The results of the analysis show that financial targets have a positive effect on financial statement frauds, so the third hypothesis (H3) is accepted. In this study, financial targets are measured by Return on Assets (ROA). The results showed that the higher the value of ROA owned by the company, the higher the value of F-Score which is a proxy of financial statement frauds. High ROA shows that the company has a great opportunity to increase the company's growth.

Rengganis, R. M. Y. D., Sari, M. M. R., Budiasih, I., Wirajaya, I. G. A., \& Suprasto, H. B. (2019). The fraud diamond: element in detecting financial statement of fraud. International Research Journal of Management, IT and 
Every company has a profit target to be achieved. Achieving the company's profit target is in line with what is expected to attract investors' attention to the company. This tends to encourage management to manipulate in order to show that the company has succeeded in achieving the profit target. Especially when the condition of the company is actually unable to meet the profit target set previously.

This is in line with the research of Skousen et al., (2009) and Widarti (2015), which found that financial target variables had a positive effect on financial statement frauds. Research of Rachmania (2017), also shows that financial targets with a proxy for return on assets (ROA) ratio affect financial report fraud. The financial target is one of the proxies of the element of pressure which is an element in the fraud diamond theory. The results of this study support fraud diamond theory which proves that pressure elements that are proxied by financial target variables can be used to detect financial statement frauds.

\subsection{The influence of the amount of the Audit Committee on the financial statement fraud}

The results of the analysis show audit committees number negatively affect the financial statement, so the fourth hypothesis (H4) is accepted. This implies the more audit committees within the company, the lower the F-Score value which is a proxy for financial statement frauds. This shows that the audit committee owned by the company has carried out the oversight function so that it can reduce the level of financial statement frauds. Specific criteria controlled by individuals who hold positions as audit committees are also a factor in the success of the oversight function implemented. That is, only people who are competent and meet the requirements can become audit committees.

The results of this study support previous studies conducted by Lin et al., (2006) and Skousen et al., (2009), proof that the proportion of members of the Independent Audit Committee (IND) negatively affects financial statement frauds. The quantity of audit committees is one of the proxies of the element of opportunity which is an element in the fraud diamond theory. The results of this study support fraud diamond theory which proves that the element of opportunity proxied by the variable number of audit committees can be used to detect financial statement frauds.

\subsection{The influence of the independent Commissioner on the financial statement fraud}

The results of the analysis show that independent commissioners have a negative effect on financial statement frauds, so the fifth hypothesis (H5) is accepted. The results of this study indicate that the greater the percentage of independent commissioners in the company, the lower the value of F-Score which is a proxy of financial statement frauds. This means that the role of the independent board of commissioners has succeeded in increasing the effectiveness of management oversight and can prevent financial statement frauds. The success of independent commissioners in increasing the effectiveness of supervision can be realized because individuals who serve as independent commissioners are competent people, have high responsibility and loyalty to the company so that they are able to work optimally in carrying out their supervisory functions. The higher percentage of independent commissioners in the company, the lower the fraud rate.

The results of this study support the research conducted by Andayani (2010), which concluded that independent Commissioners play a role in minimizing financial statement fraud committed by management. The results of research conducted by Tiffani \& Marfuah (2015), also show that ineffective monitoring has an effect on fraudulent financial reporting. An independent commissioner is one of the proxies of the element of opportunity which is an element in the fraud diamond theory. The results of this study support fraud diamond theory which proves those opportunity elements that are proxied by independent commissioner variables can be used to detect financial statement frauds.

\subsection{The influence of the number of meetings of the Audit Committee on the financial statement fraud}

The results of the analysis show that the number of audit committee meetings have a negative effect on financial statement frauds, so the sixth hypothesis (H6) is accepted. Based on the results of this study, it is illustrated that the meeting conducted by the audit committee in the company has been effective to discuss the findings of supervision. The intensity of the audit committee meetings also represents a better monitoring process and can further reduce the chances of financial statement frauds.

The results of this study support previous research conducted by Abbott et al., (2004), which prove that companies with audit committees that meet at least four times a year tend not to restatement financial statements so that there will be a negative relationship between the number of annual committee meetings audit with financial statement frauds. Research of Beasley et al., (2000), also explained that in companies that commit fraud, it is because the audit committee 
meets less often than the audit committee of companies that do not commit fraud. The number of audit committee meetings is one proxy of the element of opportunity which is an element in the fraud diamond theory. The results of this study support fraud diamond theory which proves that the element of opportunity proxied by the variable number of audit committee meetings can be used to detect financial statement frauds.

\subsection{The influence of the audit opinion on the financial statement fraud}

The results of the analysis show that the audit opinion has no effect on financial statement frauds, so the seventh hypothesis $(\mathrm{H} 7)$ is rejected. The results of the study indicate that companies that receive WTP opinions are not necessarily free from financial statement frauds and vice versa. This is probably due to the detection of irregularities or errors that occur in the financial statements. The cause of the detection of such deviations may be caused by the basis of the use of accrual accounting which is permitted by financial accounting standards, management can freely modify financial statements to produce the desired amount of profit in the use of accrual basis to show good performance in generating value or profit (Halim et al., 2005).

Madyakusumawati (2013), who figured it out that audit opinion had no effect on fraudulent financial reporting. The audit opinion is a proxy of the elements of rationalization which are elements in the fraud diamond theory. The results of this study do not support fraud diamond theory which shows that the elements of rationalization proxied by audit opinion variables cannot be used to detect financial statement frauds.

\subsection{The influence of the change of Directors at the financial statement fraud}

The results of the analysis show that changes in the Board of Directors have no effect on financial statement frauds, so the eighth hypothesis (H8) is rejected. In this study, to measure capability, a proxy change of directors was used. The results of the study indicate that the change of directors that occurred in the company was not to cover up fraud committed by previous directors but because of other factors.

Some of the things that might be the basis for the change of directors are the desire to improve the performance of the company by the company's stakeholders by recruiting directors who are considered more competent. In addition, changes in the board of directors can also be done due to the expiration of the term of office of the members of the board of directors and the board of directors who resign so that the company is deemed necessary to recruit new directors. This research is consistent with Sihombing's (2014) and Rahmayuni's (2018), research which found that capabilities proxied by the change of directors did not affect the possibility of financial statement frauds. The change in directors is a proxy for the capability element which is an element in the fraud diamond theory. The results of this study do not support fraud diamond theory which shows that the element of capability that is proxied by the change of director's variable cannot be used to detect financial statement frauds.

\section{Conclusion}

The results of the analysis of this study are pressure elements indicating that only financial target variables have a positive effect on financial statement frauds. The opportunity element shows the variable number of audit committees, independent commissioners and the number of audit committee meetings that have a negative effect on financial statement frauds. The rationalization element shows that the audit opinion variable has no effect on financial statement frauds. The capability element shows that the change of director's variable has no effect on financial statement frauds.

\section{Conflict of interest statement and funding sources}

The authors declared that they have no competing interest. The study was financed by personal funding.

\section{Statement of authorship}

The authors have a responsibility for the conception and design of the study. The authors have approved the final article.

Acknowledgments

The authors would like acknowledge to the editor of IRJMIS for their valuable time, support, and advice.

Rengganis, R. M. Y. D., Sari, M. M. R., Budiasih, I., Wirajaya, I. G. A., \& Suprasto, H. B. (2019). The fraud

diamond: element in detecting financial statement of fraud. International Research Journal of Management, IT and

Social Sciences, 6(3), 1-10. https://doi.org/10.21744/irjmis.v6n3.621 


\section{References}

Abbott, L. J., Parker, S., \& Peters, G. F. (2004). Audit committee characteristics and restatements. Auditing: A Journal of Practice \& Theory, 23(1), 69-87. https://doi.org/10.2308/aud.2004.23.1.69

ACFE. (2016). Report to Nations. Association of Certified Fraud Examiners. Austin. https://www.acfe.com/rttn2016/docs/2016-report-to-the-nations.pdf

Andayani, T. D. (2010). Pengaruh Karakteristik Dewan Komisaris Independen Terhadap Manajemen Laba (Studi Pada Perusahaan Manufaktur yang Terdaftar di Bursa Efek Indonesia) (Doctoral dissertation, Universitas Diponegoro). http://eprints.undip.ac.id/24277/1/Tutut_Dwi_Andayani.pdf

Ardiyani, S., \& Utaminingsih, N. S. (2015). Analisis Determinan Financial Statement Melalui Pendekatan Fraud Triangle. Accounting Analysis Journal, 4(1). https://doi.org/10.15294/aaj.v4i1.7761

Beasley, M. S., Carcello, J. V., Hermanson, D. R., \& Lapides, P. D. (2000). Fraudulent financial reporting: Consideration of industry traits and corporate governance mechanisms. Accounting Horizons, 14(4), 441-454. https://doi.org/10.2308/acch.2000.14.4.441

Brennan, N. M., \& McGrath, M. (2007). Financial statement fraud: incidents, methods and motives. Australian Accounting Review, 17(2), 42.

CNN. Indonesia. Kasus SNP Finance, Bank Mandiri Pidanakan Deloitte Indonesia. 26 September 2018. https://www.cnnindonesia.com/ekonomi/20180925191223-78-333175/kasus-snp-finance-bank-mandiripidanakan-deloitte-indonesia

Cressey, D. R. (1953). Other people's money; a study of the social psychology of embezzlement. https://psycnet.apa.org/record/1954-06293-000

Cressey, D. R. (1953). Other people's money; a study of the social psychology of embezzlement. https://psycnet.apa.org/record/1954-06293-000

Daljono, M. (2013). Pendeteksian Kecurangan Laporan Keuangan Melalui Faktor Risiko Tekanan Dan Peluang (Studi Kasus Pada Perusahaan Yang Mendapat Sanksi Dari Bapepam Periode 2002-2006). Diponegoro Journal of Accounting, 2(2), 1-12.

Dalnial, H., Kamaluddin, A., Sanusi, Z. M., \& Khairuddin, K. S. (2014). Detecting Fraudulent Financial Reporting through Financial Statement Analysis. Journal of Advanced Management Science. https://doi.org/10.12720/joams.2.1.17-22

Effendi, M. A. (2009). The power of good corporate governance: teori dan implementasi. Jakarta: Salemba Empat.

Indarti, N., \& Kusuma, G. H. (2016, December). Types of knowledge transferred in family business succession. In 2016 IEEE International Conference on Industrial Engineering and Engineering Management (IEEM) (pp. 646650). IEEE. https://doi.org/10.1109/IEEM.2016.7797955

Indriani, P. (2017). Fraund Diamond dalam Mendeteksi Kecurangan Laporan Keuangan. I-Finance: a Research Journal on Islamic Finance, 3(2), 161-172. https://doi.org/10.19109/ifinance.v3i2.1690

Lin, J. W., Li, J. F., \& Yang, J. S. (2006). The effect of audit committee performance on earnings quality. Managerial Auditing Journal, 21(9), 921-933. https://doi.org/10.1108/02686900610705019

Madyakusumawati, S. (2013). Faktor-Faktor Yang Mempengaruhi Kecenderungan Kecurangan Akuntansi: Corporate Governance, Transaksi Hubungan Istimewa, Kepemilikan Keluarga, Akuisisi dan Jenis Kantor Auditor-Studi Pada Perusahaan Publik Di Indonesia. Jurnal Riset Dan Konsep Manajemen. 8(1), 76-97.

Maghfiroh, N., Ardiyani, K., \& Syafnita, S. (2015). Analisis pengaruh financial stability, personal financial need, external pressure, dan ineffective monitoring pada financial statement fraud dalam perspektif fraud. Jurnal Ekonomi dan bisnis, 16(1). http://jurnal.unikal.ac.id/index.php/jebi/article/viewFile/321/302

Manurung, D. T., \& Hardika, A. L. (2015). Analysis of factors that influence financial statement fraud in the perspective fraud diamond: Empirical study on banking companies listed on the Indonesia Stock Exchange year 2012 to 2014. http://repo.uum.edu.my/17583/1/279-ICAS2015\%20279-286.pdf

Mutmainnah, N., \& Wardhani, R. (2013). Analisis dampak kualitas komite audit terhadap kualitas laporan keuangan perusahaan dengan kualitas audit sebagai variabel moderasi. Jurnal Akuntansi dan Keuangan Indonesia, 10(2), 147-170. http://dx.doi.org/10.21002/jaki.2013.08

Norbarani, L., \& Rahardjo, S. N. (2012). Pendeteksian kecurangan laporan Keuangan dengan analisis fraud Triangle yang diadopsi dalam sas no. 99 (Doctoral dissertation, Fakultas Ekonomika dan Bisnis). http://eprints.undip.ac.id/35524/1/Skripsi_32.pdf

Prasastie, A., \& Gamayuni, R. R. (2015). Analisis Faktor-Faktor yang Memengaruhi Kecurangan Laporan Keuangan dengan Perspektif Fraud Diamond (Studi Empiris pada Perusahaan LQ-45 yang Terdaftar di BEI Tahun 20092013). Jurnal Akuntansi Dan Keuangan, 20(1), 19. 
Purba, E. L. D., \& Putra, S. (2017). Analisis Fraud Diamond Dalam Mendeteksi Financial Statement Fraud: Studi Empiris Pada Perusahaan Manufaktur Yang Terdaftar Di Bursa Efek Indonesia (BEI) Tahun 2015. JAKPI-Jurnal Akuntansi, Keuangan \& Perpajakan Indonesia, https://jurnal.unimed.ac.id/2012/index.php/eua/article/view/7608

Rachmania, A., Slamet, B., \& Iryani, L. D. (2017). Analisis Pengaruh Fraud Triangle Terhadap Kecurangan Laporan Keuangan Pada Perusahaan Makanan dan Minuman Yang Terdaftar di Bursa Efek Indonesia Periode 20132015. Jurnal Online Mahasiswa (JOM) Bidang Akuntansi, $2(2)$. http://jom.unpak.ac.id/index.php/akuntansi/article/view/569/523

Rachmawati, K. K., \& Marsono, M. (2014). Pengaruh Faktor-Faktor dalam Perspektif Fraud Triangle Terhadap Fraudulent Financial Reporting (Studi Kasus pada Perusahaan Berdasarkan Sanksi dari Bapepam Periode 20082012)(Doctoral dissertation, Fakultas Ekonomika dan Bisnis). http://eprints.undip.ac.id/43002/1/01_rachmawati.pdf

Rahmadani, M. (2013). Pengaruh Manajemen Laba Pada Tingkat Pengungkapan Laporan Keuangan Pada Perusahaan Manufaktur yang Terdaftar di Bursa Efek Indonesia. http://repository.usu.ac.id/handle/123456789/38253

Rahmayuni, S. (2018). Analisis Pengaruh Fraud Diamond terhadap Kecurangan Laporan Keuangan (Studi Empiris pada Perusahaan Manufaktur yang Terdaftar di BEI Tahun 2013-2016). Jurnal Akuntansi, 6(1). http://ejournal.unp.ac.id/students/index.php/akt/article/view/2951/2177

Ristianingsih, I. (2018). Telaah konsep fraud diamond theory dalam mendeteksi perilaku fraud di perguruan tinggi. Unej e-Proceeding, 128-139. https://jurnal.unej.ac.id/index.php/prosiding/article/view/6731/4882

Sihombing, K.S., \& Shiddiq, N.R. (2014). "Analisis Fraud diamond dalam Mendeteksi Financial Statement Fraud: Studi Empiris pada Perusahaan Manufaktur yang Terdaftar di Bursa Efek Indonesia (BEI) Tahun 2010-2012”. Diponegoro Journal of Accounting. Universitas Diponegoro.

Skousen, C. J., \& Twedt, B. J. (2009). Fraud in emerging markets: A cross country analysis. Cross Cultural Management: An International Journal, 16, 301-316. https://ssrn.com/abstract=1340586

Terzaghi, M. T. (2017). Dampak Penerapan IFRS pada Nilai Perusahaan (Book Value) Jakarta Islamic Index. Jurnal MBiA, 16(2), 107-116. http://jurnal.binadarma.ac.id/index.php/jurnalmbia/article/view/559/312

Tiffani, L., \& Marfuah, M. (2015). Deteksi financial statement fraud dengan analisis fraud triangle pada perusahaan manufaktur yang terdaftar di bursa efek Indonesia. Indonesian Journal of Accounting and Auditing, 19(2), 112125. http://journal.uii.ac.id/JAAI/article/view/4330

Wahyuni, W., \& Budiwitjaksono, G. S. (2017). Fraud triangle sebagai pendeteksi kecurangan laporan keuangan. Jurnal Akuntansi, 21(1), 47-61. http://dx.doi.org/10.24912/ja.v21i1.133

Wicaksono, G. S., \& Chariri, A. (2015). Mekanisme corporate governance dan kemungkinan kecurangan dalam pelaporan keuangan. Diponegoro Journal of Accounting, 4(4), 552-563. https://ejournal3.undip.ac.id/index.php/accounting/article/view/9671/9394

Widarti. (2015). "Pengaruh Fraud Triangle Terhadap Deteksi Kecurangan Laporan Keuangan pada Perusahaan Manufaktur yang Terdaftar di Bursa Efek Indonesia (BEI)”. Jurnal Manajemen dan Bisnis Sriwijaya.

Wolfe, D. T., \& Hermanson, D. R. (2004). The fraud diamond: Considering the four elements of fraud. https://digitalcommons.kennesaw.edu/facpubs/1537/

Wolfe, D. T., \& Hermanson, D. R. (2004). The fraud diamond: Considering the four elements of fraud. https://digitalcommons.kennesaw.edu/facpubs/1537/

Rengganis, R. M. Y. D., Sari, M. M. R., Budiasih, I., Wirajaya, I. G. A., \& Suprasto, H. B. (2019). The fraud diamond: element in detecting financial statement of fraud. International Research Journal of Management, IT and Social Sciences, 6(3), 1-10. https://doi.org/10.21744/irjmis.v6n3.621 


\section{Biography of Authors}

\begin{tabular}{|c|c|}
\hline & $\begin{array}{l}\text { RR. Maria Yulia Dwi Rengganis, SE was born on July 4th, } 1995 \text { in Denpasar. She is a } \\
\text { college student in the master of accounting at the faculty of economics and business, } \\
\text { Universitas Udayana. She lives at J1. Kusuma Bangsa II no 3A, Gatsu Barat. She } \\
\text { graduated her bachelor degree in Faculty of Economics and Business, Udayana } \\
\text { University, Bali in 2016. } \\
\text { Email:dwiyuliaa67@gmail.com }\end{array}$ \\
\hline & $\begin{array}{l}\text { Dr. Maria Mediatrix Ratna Sari, SE., M.Si., Ak., CA was born on August 9th, 1965, in } \\
\text { Pasuruan. She is a lecturer in the faculty of economics and business, Udayana University. } \\
\text { She lives at Jl. Tukad Batanghari Gg 14a No 14, Denpasar 80225. She graduated her } \\
\text { bachelor degree in Accounting, Udayana University. She Finished her Master of } \\
\text { Financial Accounting at Gajah Mada University. And she finished her doctorate in } \\
\text { Brawijaya University. } \\
\text { Email: maria.ratna65@unud.ac.id }\end{array}$ \\
\hline & $\begin{array}{l}\text { Dr. I Gusti Ayu Nyoman Budiasih, S.E., M.Si., CSRS., CSRA was born on January 15th, } \\
1969 \text { in Denpasar. She is a lecturer in the faculty of economics and business, Udayana } \\
\text { University. She lives at Jalan Dukuh I No. } 10 \text { Gatsu Timur Denpasar. She graduated her } \\
\text { bachelor degree in Accounting, Udayana University. She Finished her Master of } \\
\text { Financial Accounting at Gajah Mada University. And she finished her doctorate in } \\
\text { Brawijaya University. } \\
\text { Email: iganbudiasih17@gmail.com }\end{array}$ \\
\hline $1 \mathrm{in}$ & $\begin{array}{l}\text { Dr. I Gde Ary Wirajaya, SE., M.Si was born on February 4th, 1978, in Singaraja. He is } \\
\text { a lecturer in the faculty of economics and business, Udayana University. He lives at Jl. } \\
\text { Tukad Melangit No.61 Denpasar. He graduated his bachelor degree in Accounting, } \\
\text { Udayana University. He Finished his Master of Accounting at Udayana University. And } \\
\text { he finished his doctorate at Brawijaya University. } \\
\text { Email: ary_wirajaya@yahoo.com }\end{array}$ \\
\hline & $\begin{array}{l}\text { Dr. Drs. Herkulanus Bambang Suprasto, M.Si., Ak., CA was born on August 28th, 1963, } \\
\text { in Denpasar. He is a lecturer in the faculty of economics and business, Udayana } \\
\text { University. He lives at Jl. Kusuma Bangsa II, Denpasar. He graduated his bachelor degree } \\
\text { in Accounting, Airlangga University. He Finished his Master of Financial Accounting at } \\
\text { Gajah Mada University. And he finished his doctorate at Brawijaya University. } \\
\text { Email: herculanusbambang2017@gmail.com }\end{array}$ \\
\hline
\end{tabular}

